\title{
Pengaruh Lokus Pengendalian dan Pengetahuan Keuangan pada Perilaku Manajemen Keuangan Generasi Milenial dengan Moderasi Pendapatan
}

\author{
Indria Fatmawati ${ }^{1)}$, Lutfi Lutfi ${ }^{2 *}$ ) \\ ${ }^{1,2 *}$ Program Studi Sarjana Manajemen, STIE Perbanas Surabaya \\ Rungkut, Surabaya, Jawa Timur, 60296 \\ E-mail:lutfi@perbanas.ac.id
}

\begin{abstract}
ABSTRAK
Penelitian ini berupaya untuk mengkaji pengaruh dari lokus pengendalian dan pengetahuan keuangan pada perilaku manajemen keuangan generasi milenial dengan pendapatan sebagai moderator. Sampel penelitian ini adalah 216 responden generasi milenial berusia 20 - 39 tahun, yang berdomisili di Surabaya, Gresik dan Sidoarjo. Analisis data menggunakan model persamaan struktural (PLS-SEM). Temuan penelitian membuktikan bahwa lokus pengendalian dan pengetahuan keuangan berdampak positif secara signifikan signifikan pada perilaku keuangan generasi milenial. Sebaliknya, pendapatan tidak terbukti berpengaruh signifikan tpada perilaku keuangan. Selain itu, tidak terdapat bukti signifikan bahwa pedapatan mampu memperkuat pengaruh pengetahuan keuangan terhadap perilaku keuangan. Hal ini berarti generasi milenial perlu meningkatkan pengetahuan keuangan serta keyakinan dan kemampuan dalam mengendalikan kondisi keuangan.
\end{abstract}

Kata kunci: Perilaku Manajemen Keuangan; Pengetahuan Keuangan; Lokus Pengendalian; Generasi Milenial

\begin{abstract}
This study aims to analyze the influence of locus of control and financial knowledge on the financial management behavior of the millennial generation by using income as a moderator. The sample of this study was 216 respondents from the millennia lgeneration aged 20 - 39 years, who live in Surabaya, Gresik and Sidoarjo. Data is analyzed using partial least square - structural equation modeling (PLS-SEM). The results show that the locus of control and financial knowledge significantly impact on the financial behavior of the millennial generation. Conversely, income has no significant effect on financial behavior. In addition, there is no significant evidence that income is able to strengthen the effect of financial knowledge on financial behavior. This means that the millennial generation needs to increase their financial knowledge and confidence and ability to control financial conditions.
\end{abstract}

Keyword: Financial Behavior, Financial Knowledge, Locus of Control, Millennial Generation.

\section{PENDAHULUAN}

Pengelolaan keuangan yang baik dapat menjadi acuan untuk menata masa depan yang lebih sejahtera dan terhindar dari hal-hal yang tidak diinginkan seperti kebangkrutan atau kesulitan memenuhi kebutuhan hidup. Perilaku keuangan pribadi berkaitan dengan bagaimana seseorang mengelola dananya untuk memenuhi kebutuhan hidup (Xiao, 2008). Pada hakekatnya, perilaku keuangan meliputi kegiatan yang berhubungan dengan pengelolaan 
peghasilan, pengeluaran, utang, simpanan dan investasi, serta suransi (Hilgert et al., 2003). Dengan demikian, perilaku keuangan berkaitan dengan pengelolaan pendapatan dan penggunaan pendapatan tersebut untuk memenuhi kebutuhan konsumsi hari ini dan menyisihkannya untuk kebutuhan di masa depan (Brilianti \& Lutfi, 2020; Perry \& Morris, 2005). Individu yang lebih bertanggungjawab dalam mengelola keuangannya cenderung lebih efektif dalam memanfaatkan uang yang dimilikinya, seperti menyusun anggaran, menghemat uang dan mengendalikan belanja, berinvestasi, serta membayar tagihan dan utang tepat waktu (Nababan \& Sadalia, 2012).

Perilaku manajemen keuangan pada generasi milenial menjadi fenomena yang sangat menarik untuk diteliti. Saat ini generasi milenial merupakan generasi dengan usia yang produktif dimana generasi milenial memiliki pekerjaan yang lebih variatif dan kompeten dibanding generasi sebelumnya. Generasi milenial juga memiliki pendapatan yang cukup besar. Hal yang menjadi masalah adalah kebanyakan penghasilannya dihabiskan untuk menemuhi gaya hidup. Gaya hidup generasi milenial yang bisa dikatakan kurang sehat karena kebanyakan generasi milenial menabung bukan untuk membeli aset ataupun menggunakan untuk modal usaha, tetapi lebih mementingkan gaya hidup seperti membeli minuman kekinian (kopi dan boba), nongkrong, belanja, bahkan sering melakukan liburan hura-hura (Lubis, 2020).

Mempertimbangkan fenomena tersebut, peneliti akan mengkaji faktor yang memengaruhi perilaku keuangan generasi milenial, yaitu lokus pengendalian, pengetahuan keuangan dan pendapatan. Lokus pengendalian yang digunakan dalam penelitian ini adalah lokus pengendalian internal. Lokus pengendalian internal dalam individu dapat diartikan sebagai keyakinan individu bahwa apa yang terjadi pada dirinya tergantung pada apa yang telah diupayakannya (Kholilah \& Iramani, 2013). Individu dengan dengan lokus pengendalian internal cenderung lebih percaya diri dan meyakini bahwa penentu keberhasilan adalah dirinya sendiri, bukan faktor eksternal (Ariani et al., 2016). Jika sesorang memiliki lokus pengendalian yang baik maka seseorang tersebut dapat lebih bertanggung jawab terhadap perilaku keuangan, seperti menabung (Cobb-Clark et al., 2016; Grable et al., 2015; Strömbäck et al., 2017). Hal tersebut dikarenakan individu dapat mengontrol diri untuk menggunakan atau mengelola uang dengan teliti dan baik (Kholilah \& Iramani, 2013; Kusnandar et al., 2018).

Perilaku manajemen keuangan yang baik juga tidak bisa lepas dari pengetahuan yang dimiliki oleh seseorang. Perry \& Morris (2005) mengungkapkan bahwa pengetahuan keuangan merupakan faktor krusial dalam mengatasi masalah keuangan. Seseorang dengan 
pengetahuan keuangan lebih baik cenderung lebih bijaksana dalam mengelola keuangannya (Arifin et al., 2017; Brilianti \& Lutfi, 2020; Ida \& Dwinta 2010; Iramani \& Lutfi, 2021; Grohmann 2018; Stolper \& Walter (2017). Hal tersebut disebabkan karena individu akan mengerti pentingya menyiapkan anggaran, berinvestasi, asuransi maupun menggunakan kredit akan mengaplikasikan pengetahuan tersebut dalam pengelolaan keuangan sehari-hari.

Pendapatan menjadi salah satu faktor lain penentu perilaku keuangan karena apabila seseorang berpenghasilan lebih tinggi maka orang tersebut akan lebih leluasa dalam mengelolaan keuangannya (Henager \& Mauldin, 2015). Individu dengan pendapatan yang lebih tinggi akan memiliki lebih banyak dana untuk dikelola yang bermanfaat bagi kehidupan saat ini maupun masa depan, seperti menabung, investasi, persiapan hari tua. Semakin tinggi pendapatan yang dimiliki individu, semakin memiliki perilaku keuangan yang lebih baik, mengingat individu memiliki uang untuk ditabung maupun diinvestasi. Brilianti \& Lutfi (2020) dan Heckman \& Hanna (2015) membuktikan bahwa tingkat pendapatan menyebabkan terjadinya perbedaan perilaku keuangan seseorang. Putri \& Tasman (2019) juga memberi bukti bahwa semakin tinggi penghasilan maka semakin baik perilaku keuangan. Sebaliknya, Arifin et al. (2017) dan Ida \& Dwinta (2010) tidak menemukan bukti yang meyakinkan adanya pengaruh penghasilan terhadap perilaku keuangan.

Selain berpengaruh terhadap perilaku keuangan, pendapatan dapat memperkuat atau memperlemah pegaruh pengetahuan keuangan terhadao perilaku keuangan. Semakin seseorang memiliki pengetahuan keuangan yang banyak dan didukung dengan pendapatan yang tinggi maka individu dapat memiliki perilaku keuangan yang baik. Hal tersebut dikarenakan dengan adanya pendapatan yang semakin besar maka individu yang memiliki pengetahuan keuangan baik memiliki lebih banyak kemudahan dalam menerapkan pengetahuan yang dimiliki oleh mengelola keungaannya dengan baik pula, seperti membayar tagihan dengan tepat waktu, membuat anggaran maupun perencanaan untuk masa depan, menabung untuk membeli aset maupun berinvestasi serta pemanfaatan hutang untuk kesejahteraan, maka dari itu muncul perilaku keuangan yang baik. Berbeda dengan individu yang memiliki pengetahuan yang baik akan tetapi pendapatannya tergolong rendah maka individu tersebut belum tentu bahkan tidak bisa memiliki perilaku keuangan yang baik. Hal tersebut dikarenakan individu hanya memiliki pengetahuan keuangan akan tetapi tidak memiliki cukup dana untuk dikelola sehingga bisa kesulitan dalam membayar tagihan dengan tepat waktu, kesulitan untuk menabung maupun berinvestasi. Perry \& Morris (2005) membuktikan bahwa pendapatan memperkuat pengaruh pengetahuan keuangan terhadap perilaku keuangan. 
Berdasarkan uraian latar belakang tersebut maka peneliti ingin mengkaji mengenai perilaku keuangan dengan fokus pada generasi generasi milenial. Penelitian perilaku keuangan pada generasi ini perlu dilakukan karena memiki karakteristik berbeda dengan generasi lainnya, seperti perilaku narsisme, pencarian sensasi, harga diri, dan belanja online (Brailovskaia \& Bierhoff, 2020). Generasi milenial juga menduduki proporsi terbesar kedua penduduk di Indonesia, yaitu 69 juta atau 26 persen (Badan Pusat Statistik, 2020). Generasi milenial menghadapi berbagai alternatif keputusan keuangan yang cukup rumit, termasuk membayar kebutuhan pribadi atau sulitnya membedakan kebutuhan yang primer, sekunder ataupun tersier (Putri \& Tasman, 2019).

Keterbaruan penelitian ini adalah menggunakan pendapatan sebagai variabel pemoderasi dari dampak pengetahuan keuangan pada perilaku manajemen keuangan. Penelitian yang dilakukan di Indonesia sejauh ini menggunakan pendapatan sebagai bebas yang mempengaruhi perilaku manajemen keuangan (Purwidianti \& Mudjiyanti, 2016, Putri \& Tasman, 2019). Seseorang dengan pemahaman keuangan yang mumpuni dan dibarengi dengan penghasilan yang lebih tinggi cenderung akan mengelolan keuangannya dengan lebih bijak dibanding orang yang berpenghasilan lebih rendah karena tersedianya kelebihan dana yang dapat dikelola.

\section{METODE PENELITIAN}

Penelitian ini menggunakan variabel terikat yaitu perilaku keuangan (PK), variabel bebas yaitu lokus pengendalian (LP), pengetahuan keuangan (PK), dan pendapatan (Pd). Perilaku keuangan berkaitan dengan kemampuan seseorang dalam mengatur keuangan untuk memenuhi kebutuhan hidup sekarang dan di masa depan. Menurut Dew \& Xiao (2011), indikator variabel perilaku keuangan meliputi konsumsi, manajemen kas, tabungan dan investasi, serta manajemen kredit. Skala pengukurannya adalah skala Likert mulai (1) Tidak pernah hinga (5) Selalu. Lokus pengendalian menunjukkan bagaimana seseorang memandang suatu peristiwa, yaitu apakah yang terjadi pada dirinya tergantung pada apa yang telah diusahakan atau faktor eksternal. Menurut Rotter (1966), indikator variabel lokus pengendalian mencakuo kemampuan dalam membuat keputusan keuangan, perasaan dalam menjalani hidup, kapasitas untuk mengubah hal penting dalam kehidupan, kapasitas dalam meralisasi ide, keyakinan terhadap masa depan, dan kapasitas dalam mengatasi masalah keuangan. Skala pengukurannya adalah skala Likert, yaitu mulai (1) Sangat tidak setuju hingga (5) Sangat setuju. Pengetahuan keuangan merupakan pemahaman dan kemampuan seseorang terkait bidang keuangan, alat keuangan dan keterampilan keuangan. Menurut Chen 
\& Volpe (1998), indikator variabel pengetahuan keuangan meliputi pengetahuan keuangan umum, tabungan dan pinjaman, investasi, serta asuransi. Skala pengukurannya adalah dengan menggunakan skala rasio, yang diukur berdasarkan persentase jawaban benar dan terhadap seluruh pertanyaan.

Populasi dari penelitian ini adalah generasi milenial, yaitu mereka yang lahir pada periode tahun 1980-2000. Penelitian ini menggunakan teknik pengambilan sampel non random, yaitu purposive sampling. Teknik ini mengambil sampel dari populasi berdasarkan kriteria yang telah ditetapkan dengan mengacu pada tujuan dari penelitian. Adapun kriterianya yaitu berumur minimum 20 tahun dan maksimum 39 tahun, bertempat tinggal di Surabaya, Sidoarjo dan Gresik, memiliki penghasilan sendiri mininum UMK Rp 4.000.000. Pertimbangannya adalah Upah Minimm Kota (UMK) untuk Surabaya, Sidoarjo dan Gresik sekitar Rp.4.000.000.

Penelitian ini menggunakan data primer dimana pengambilan datanya melalui survei. Survei dilakukan dengan cara membagikan kuisoner kepada generasi milenial yang sudah bekerja dan menghasilkan uang sendiri. Setelah responden mengisi kuisoner, kuisoner akan dikembalikan kepada peneliti untuk diolah dan dianalisis data. Kuesioner menggunakan google form dan akan disebarkan ke media sosial seperti twitter, instagram dan melalui whatsApp. Skala yang peneliti gunakan adalah skala likert yang merupakan skala interval sebagai dasar pengkurannya

Berdasarkan pengembangan hipotesis sebelumnya, model penelitian ini dapat diilustrasikan sebagaimana disajikan pada Gambar 1. Penelitian ini menggunakan teknik analisis model persamaan simultan dengan partial least square (PLS-SEM) dengan menggunakan software SmartPLS 3.

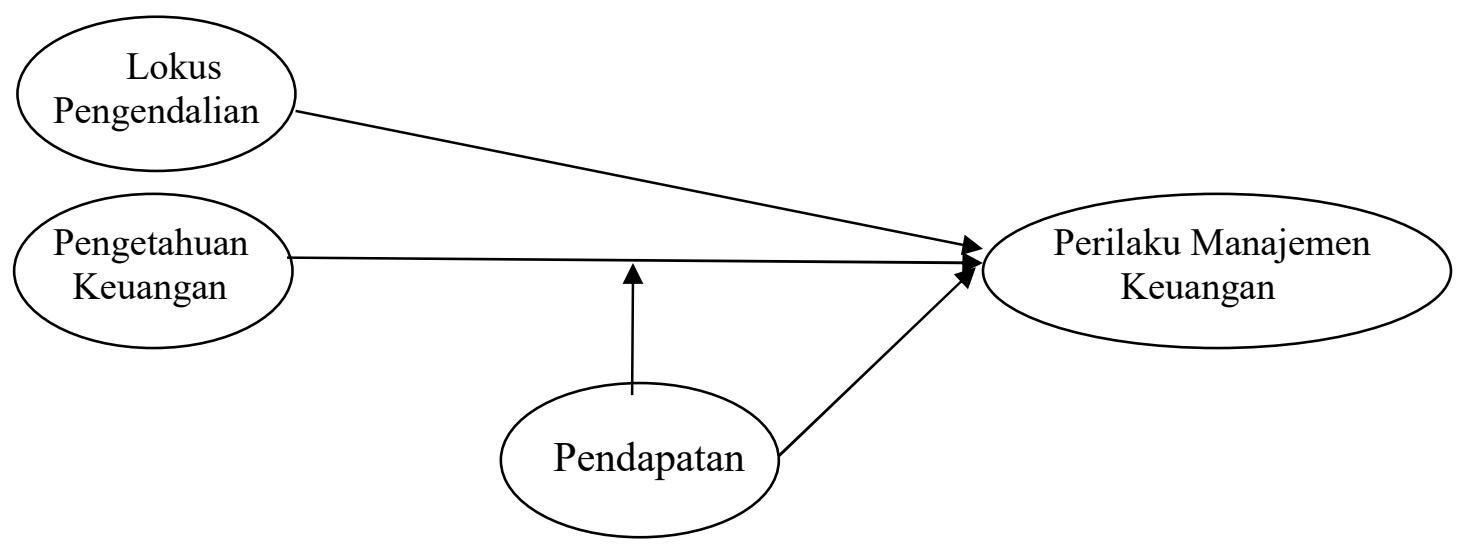

Gambar 1. Kerangka Penelitian 


\section{HASIL DAN PEMBAHASAN}

Tahap pertama dalam studi ini adalah melakukan pengujian instrumen penelitian. Tabel 1 menunjukkan hasil pengujian validitas dan reliabilitas dari instrumen penelitian. Pengujian Validitas dilakukan untuk melakukan pengujian dari kemampun instrumen penelitian dalam melakukan pengukuran obyek dan mengukur variabel yang hendak diteliti. Pengujian validitas sendiri digunakan untuk mengukur valid tidaknya suatu kuisioner. Kuesioner dapat dinyatakan valid jika pernyataan yang disampaikan dalam kuesioner mampu menjelaskan hubungan antar variabel yang sedang diukur (Ghozali \& Latan, 2013).

Nilai loading factor pada Tabel 1 untuk semua pernyataan adalah $>0,70$ sehingga semua indikator variabel adalah valid (Ghozali \& Latan, 2013). Tabel 1 juga memperlihatkan bahwa semua kosntruk memiliki cronbach's alpha dan composite reliability $>0.6$, yang berarti item reliabel (Ghozali \& Latan, 2013). Dalam penilaian discriminant validity, konstruk yang dituju harus memiliki nilai yang lebih besar daripada nilai loading konstruk lain. Untuk menilai kelayakan model berbasis PLS-SEM, penelitian ini menggunakan standardized root mean square residual (SRMR) atau root mean square residual covariance ( $\mathrm{RMS}_{\text {theta) }}$. Suatu model dikategorikan layak jika memiliki nilai SRMR $<0,08$ dan $\mathrm{RMS}_{\text {theta }}<0,12$ (Hair, 2016: 193). Tabel 1 menunjukkan bahwa model dalam penelitian ini adalah model yang baik (wellfitting model) karena memiliki nilai SRMR $=0,073$ dan dan $\mathrm{RMS}_{\text {theta }}=0,103$.

\section{Tabel 1. Hasil Pengujian Validitas dan Reliabilitas}

\begin{tabular}{|c|c|c|c|c|c|}
\hline \multirow{2}{*}{ Variabel } & \multirow{2}{*}{ Kode } & \multirow{2}{*}{ Pernyataan } & \multirow{2}{*}{$\begin{array}{c}\text { Pengujian } \\
\text { Validitas } \\
\text { Loading } \\
\text { factor } \\
\end{array}$} & \multicolumn{2}{|c|}{ Pengujian Reliabilitas } \\
\hline & & & & $\begin{array}{l}\text { Composite } \\
\text { Reliability }\end{array}$ & $\begin{array}{l}\text { Cronbach's } \\
\text { Alphs }\end{array}$ \\
\hline \multirow{5}{*}{$\begin{array}{l}\text { Perilaku } \\
\text { Manajemen } \\
\text { Keuangan } \\
(\text { PMK) }\end{array}$} & PMK1 & $\begin{array}{l}\text { Membayar tagihan secara tepat } \\
\text { waktu }\end{array}$ & $\begin{array}{c}0,784 \\
\text { (Valid) }\end{array}$ & \multirow{5}{*}{$\begin{array}{c}0,846 \\
\text { (Reliabel) }\end{array}$} & \multirow{5}{*}{$\begin{array}{c}0,757 \\
\text { (Reliabel) }\end{array}$} \\
\hline & PMK2 & Menyisihkan pendapatan untuk & 0,792 & & \\
\hline & & ditabung setiap bulan & (Valid) & & \\
\hline & PMK3 & $\begin{array}{l}\text { Menyisihkan pendapatan untuk } \\
\text { investasi setiap bulan }\end{array}$ & $\begin{array}{l}0,706 \\
\text { (Valid) }\end{array}$ & & \\
\hline & PMK4 & $\begin{array}{l}\text { Membayar hutang secara tepat } \\
\text { waktu }\end{array}$ & $\begin{array}{l}0,760 \\
\text { (Valid) }\end{array}$ & & \\
\hline \multirow{4}{*}{$\begin{array}{l}\text { Lokus } \\
\text { Pengendalian } \\
\text { (LP) }\end{array}$} & LP1 & $\begin{array}{l}\text { Mampu membuat keputusan } \\
\text { masalah keuangan }\end{array}$ & $\begin{array}{l}0,753 \\
\text { (Valid) }\end{array}$ & \multirow{5}{*}{$\begin{array}{c}0,863 \\
\text { (Reliabel) }\end{array}$} & \multirow{5}{*}{$\begin{array}{c}0,792 \\
\text { (Reliabel) }\end{array}$} \\
\hline & LP2 & $\begin{array}{l}\text { Mampu melakukan hal-hal } \\
\text { penting yang berguna bagi } \\
\text { kesejahteran keuangan }\end{array}$ & $\begin{array}{l}0,775 \\
\text { (Valid) }\end{array}$ & & \\
\hline & LP3 & $\begin{array}{l}\text { Mampu menyelesaikan } \\
\text { masalah keuangan }\end{array}$ & $\begin{array}{c}0,769 \\
\text { (Valid) }\end{array}$ & & \\
\hline & LP4 & $\begin{array}{l}\text { Mampu mengendalikan } \\
\text { kondisi keuangan sehari-hari }\end{array}$ & $\begin{array}{c}0,831 \\
\text { (Valid) }\end{array}$ & & \\
\hline \multicolumn{3}{|c|}{ Model Fit Summary: SRMR $=0,073$; RMStheta $=0,103$} & & & \\
\hline
\end{tabular}


Tabel 2 berikut ini menjelaskan bahwa nilai akar AVE dan besaran korelasi antara variabel dengan variabel itu sendiri (dicetak tebal) adalah lebih tinggi daripada nilai AVE dan nilai korelasi antara variabel tersebut dengan variabel yang lain. Dengan demikian, item-item pernyataan pada dalam setiap konstruk dapat mengukur konstruk tersebut dengan baik.

Tabel 2. Hasil Uji Discriminant Validity

\begin{tabular}{ccc}
\hline & PMK & LP \\
\cline { 2 - 3 } & \multicolumn{2}{c}{ AVE } \\
\hline PMK & $\mathbf{0 , 7 6 1}$ & 0,484 \\
LP & 0,484 & $\mathbf{0 , 7 8 3}$ \\
& PMK & LP \\
PMK1 & $\mathbf{0 , 7 8 4}$ & 0,434 \\
PMK2 & $\mathbf{0 , 7 9 2}$ & 0,305 \\
PMK3 & $\mathbf{0 , 7 0 6}$ & 0,310 \\
PMK4 & $\mathbf{0 . 7 6 0}$ & 0,428 \\
LP1 & 0,434 & $\mathbf{0 , 7 8 4}$ \\
LP2 & 0,305 & $\mathbf{0 , 7 9 2}$ \\
LP3 & 0,310 & $\mathbf{0 , 7 0 6}$ \\
LP4 & 0,428 & $\mathbf{0 . 7 6 0}$ \\
\hline
\end{tabular}

Sumber: Output Smart PLS 3 (2021)

Tabel 3 menyajikan karakteristik responden berdasarkan status perkawinan, usia dan pendapatan dari 216 responden. Tabel ini memperlihatkan bahwa persentasi responden berdasarkan status perkawinan menunjukkan bahwa persentase status perkawinan responden didominasi oleh responden yang belum menikah yaitu sebanyak $66 \%$ dan sisanya yaitu sebanyak 34\% menikah. Hal ini bisa terjadi karena responden dari penelitian ini adalah generasi milenial, dengan usia 20 - 39 tahun. Berdasarkan usianya, persentase usia responden mayoritas berusia 20-25 tahun yaitu sebanayak 56\%, responden berusia 26-35 tahun sebanyak 39\% persen dan responden yang berusia 36-39 tahun sebanyak 5\%. Berdasarkan pendapatannya, persentase total pendapatan individu responden didominasi oleh responden yang memiliki total pendapatan individu sebesar Rp 4 juta -6 juta, yaitu sebanyak $54 \%$. Hal ini sangat mungkin terjadi karena umumnya reponden baru bekerja dan belum menduduku jawaban, atau belum lama memulai usaha. Responden yang memiliki total pendapatan individu lebih dari Rp 6 juta -8 juta sebanyak 23\%, responden yang memiliki total pendapatan individu lebih dari Rp 8 juta - 10 juta sebanyak $11 \%$, responden yang memiliki total pendapatan individu lebih dari Rp 10 juta - 12 juta sebanyak 3\% dan responden yang memiliki total pendapatan individu lebih dari Rp 12 juta sebanyak sebanyak $9 \%$. 
Tabel 3. Karakteristik Responden

\begin{tabular}{lcc}
\hline & Jumlah Responden & Persentase \\
\hline Status Perkawinan: & & \\
Belum menikah & 71 & $66 \%$ \\
Menikah & 37 & $34 \%$ \\
Usia: & 60 & \\
20 - 25 tahun & 42 & $56 \%$ \\
$26-35$ tahun & 6 & $39 \%$ \\
36 - 39 tahun & & $5 \%$ \\
Pendapatan: & 58 & $\mathrm{e}$ \\
>Rp 4 juta - Rp 6 juta & 25 & $54 \%$ \\
$>$ Rp 6 juta - Rp 8 juta & 12 & $23 \%$ \\
$>$ Rp 8 juta - Rp 10 juta & 3 & $11 \%$ \\
$>$ Rp 10 juta - Rp 12 juta & 10 & $3 \%$ \\
$>$ Rp 12 juta & & $9 \%$ \\
\hline
\end{tabular}

Sumber: Data primer (2021), diolah

Tabel 4 menjelaskan deskriptif statistik variabel penelitian. Responden rata-rata memiliki perilaku manajemen keuangan adalah 3,66. Hal ini memperlihatkan jika responden penelitian melakukan pengelolaan keuangan individu dengan baik di dalam kehidupan seharihari. Tabel ini juga menunjukkan secara keseluruhan bahwa rata-rata tanggapan responden mengenai lokus pengendalian sebesar 4,25 , yang berarti bahwa responden memiliki lokus pengendalian internal atau cara pandang terhadap pengendalian dirinya yang sangat baik dalam kehidupan sehari-hari. Reponden sangat percaya bawa apa yang terjadi pada dirinya akan tergantung pada apa yang diupayakannya. Terakhir, responden memiliki pengetahuan keuangan rata-rata sebesar 58,06\%, yang berarti pengeetahuan keuangan responden relatif renda (Chen \& Volpe, 1998). Secara keseluruhan, hanya terdapat sedikit variasi dalam tingkat pengetahuan keuangan yang dimiliki responden.

Tabel 4. Analisis Deskriptif Variabel Penelitian

\begin{tabular}{lcc}
\hline \multicolumn{1}{c}{ Variabel } & Mean & Std Deviasi \\
\hline Perilaku Manajemen Keuangan & 3,66 & 1,280 \\
\hline Lokus Pengendalian (internal) & 4,25 & 0,655 \\
\hline Pengetahuan keuangan & 58,6 & 0,472 \\
\hline Sumber: Output SmartPLS 3 (2021) & &
\end{tabular}

Setelah dilakukan analisis deskriptif, selanjutnya dilakukan analisis inferensial melalui pengujian hipotesis penelitian dengan menggunakan model persamaan struktural (PLS-SEM) pada software Smart PLS 3 6.0, hasilnya ditunjukkan pada Tabel 4. Hasil pengujian menunjukkan bahwa perolehan path coefficient sebesar 0,440 yang berarti lokus pengendalian (LP) memiliki pengaruh positif terhadap perilaku manajemen keuangan, dengan besarnya thitung adalah 5,810 dan nilai $p$-values adalah 0,000. Dengan demikian, penelitian ini 
menerima H1. Berdasarkan hasil pengujian ini maka dapat disimpulkan bahwa lokus pengendalian secara signifikan berdampak positif pada perilaku keuangan generasi milenial. Hal ini berarti bahwa semakin baik lokus pengendalian seseorang maka perilaku keuangannya semakin lebih baik.

Tabel 6. Pengujian Tanpa Moderasi

\begin{tabular}{cccccc}
\hline Hipotesis & Keterangan & Koefisien & T-Statistic & P-Values & Kesimpulan \\
\hline H1 & LP $\rightarrow$ PMK & 0.437 & 5,766 & 0,000 & H0 ditolak \\
\hline H2 & PK $\rightarrow$ PMK & 0,177 & 2,273 & 0,023 & H0 ditolak \\
\hline H3 & Pd $\rightarrow$ PMK & 0,016 & 0,164 & 0,870 & H0 diterima \\
\hline H4 & PK ${ }^{*} \mathrm{Pd} \rightarrow$ PMK & 0,032 & 0,325 & 0,745 & H0 diterima \\
\hline & R-Square & \multicolumn{3}{c}{0,265} & \\
\hline
\end{tabular}

Sumber: Output SmartPLS 3 (2021)

Keterangan: $\mathrm{PMK}=$ Perilaku Manajemen Keuangan, $\mathrm{LP}=$ Lokus Pengendalian, $\mathrm{PK}=$ Pengetahuan Keuangan, $\mathrm{Pd}=$ Pendapatan

Hasil penelitian ini menunjukkan adanya pengaruh positif yang signifikan dari lokus pengendalian terhadap perilaku keuangan generasi milenial. Dengan demikian, semakin baik lokus pengendalian individu maka perilaku keuangan semakin baik. Individu yang memiliki lokus pengendalian atau kontrol diri yang baik dalam mengambil keputusan untuk menyelesaikan masalah keuangan yang berkaitan dengan kredit maka individu tersebut akan memiliki perilaku keuangan yang baik dalam membayar tagihan secara penuh dan tepat waktu. Demikian juga individu yang meyakini jika apa yang terjadi pada dirinya di kemudian hari tergantung pada apa yang telah diupayakan saat ini akan cenderung menerapkan praktek keuangan yang lebih baik, seperti secara rutin menyisihan sebagain dari pendapatan bulanan untuk tabungan dan investasi. Individu yang dapat mengendalikan kondisi keuangan seharihari maka individu memiliki perilaku keuangan yang baik dalam hal menabung dan melakukan investasi secara berkala. Hal ini juga terkait dengan generasi milenial yang memiliki karakteristik lebih percaya diri, lebih independen, berorientasi pada hasil, dan melek teknologi, dan berpikir terbuka (Arviana, 2020). Dengan karakter lebih percaya dan independen maka generasi milenial akan lebih menyiapkan masa depannya, termasuk kesejehteraan keuangannya, melalui upaya sendiri sehingga tidak menggantungkan kepada pihak lain. Hasil penelitian ini mendukung temuan Kusnandar et al. (2018) dan Kholilah \& Iramani (2013) yang memberi bukti bahwa lokus pengendalian internal memiliki pengaruh positif yang signifikan pada perilaku keuangan. Dengan demikian, ketika seseorang memiliki lokus pengendalian yang lebih baik maka orang tersebut akan mengelola keuanganya dengan lebih baik dan bijak. Akan tetapi, temuan penelitian ini mendukung Ida \& Dwinta (2010) yang memberi bukti bahwa lokus pengendalian tidak secara signifikan mempengaruhi 
perilaku keuangan.

Hipotesis kedua yang dikaji adalah bahwa pengetahuan keuangan memiliki pengaruh positif yang signifikan pada perilaku keuangan generasi milenial. Hasil studi ini memberi bukti bahwa pengetahuan keuangan secara signifikan berdampak positif pada perilaku pengelolaan keuangan generasi milenial. Dengan demikian, jika seseorang memiliki pengetahuan keuangan yang lebih maka perilaku pengelolaan keuangannya juga akan semakin bijak pula. Seseorang dengan pemahaman yang baik mengenai pengetahuan umum keuangan, seperti dapat memahami inflasi maupun time value of money maka akan menerapkan pengetahuan tersebut untuk mengelola keuanggannya, seperti kebiasan untuk menabung dan investasi. Individu tersebut menyadari bahwa salah satu cara untuk mengatasi menurunya daya beli adalah dengan menabung dan melaukan investasi yagn menghasilkan tingkat keuntungan lebih besar dari tingkat inflasi. Demikian juga invidu yang mahami bahwa nilai uang akan menurun dari waktu ke waktu akan melakukan investasi agar nilai kekayaan meningkat. Selain itu, individu yang memiliki pengetahuan keuangan yang baik mengenai tabungan dan kredit akan memiliki perilaku keuangan yang baik, seperti melakukan pembayaran tagihan secara penuh dan tepat waktu. Individu tersebut menyadari bahwa menunda pembayaran angsungan akan memperbesar biaya pinjaman (bunga) dan menyebabkan utang semakin menumpuk yang mangakibatkan permasalaha keuangan. Selanjutnya, individu yang memiliki pengetahuan keuangan yang lebih baik mengenai asuransi, seperti hasil pada penelitian ini yaitu sebanyak $62,50 \%$, menyadari bahwa masa depan penuh ketidak pastian atau berisiko sehingga individu seperti akan melakukan pengelolaan keuangannya dengan lebih baik, seperti menyisihkan pendapatannya untuk investasi, dana pensiun dan asuransi. Hasil penelitian ini mendukung temuan Brilianti \& Lutfi (2020), Arifin et al. (2017), Ida \& Dwinta (2010), dan Iramani \& Lutfi (2021) yang memberi bukti bahwa pengetahuan keuangan berpengaruh terhadap perilaku keuangan. Dengan demikian, semakin seorang generasi milenial memiliki pengetahuan yang lebih maka orang tersebut tersebut memiliki pengetahuan yang baik.

Hipotesis ketiga dalam penelitian ini adalah pendapatan berdampak positif pada perilaku keuangan generasi milenial. Hasil dalam penelitian ini membuktikan bahwa pendapatan tidak memiliki pengaruh positif secara signifikan pada perilaku keuangan generasi milenial. Hal ini berarti bahwa walaupun individu memiliki pendapatan yang tinggi maka tidak menjamin individu tersebut memiliki perilaku keuangan yang baik. Munculnya hasil yang tidak signifikan berpengaruh pengaruh pendapatan terhadap perilaku keuangan pada penelitian ini bisa dikarenakan oleh beberapa hal. Pertama, 66\% memiliki status perkawinan 
belum menikah yang memiliki sehingga sangat dimungkinkan individu dalam kelompok ini masih ingin menikmati kehidupan sebagai anak mudah dan belum banyak berfikir untuk masa depan. Kedua, pendapatan yang tinggi bisa tidak berpengaruh terhadap perilaku keuangan apabila seseorang memiliki tanggungan keluarga. Seseorang yang memiliki pedapatan yang namun dengan tanggungan keluarga yang banyak kemungkinan tidak memiliki sisa dana untuk menabung dan berinvestasi. Selain itu juga, rata-rata pendapatan responden pada penelitian ini memiliki pendapatan $>\mathrm{Rp} 4$ juta $-\mathrm{Rp} 6$ juta yang mana pendapatan tersebut dapat dihabiskan untuk kebutuhan sehari-hari. Pendapatan tersebut termasuk pendapatan terendah didalam kriteria penelitian ini. Hasil penelitian ini mendukung temuan Brilianti \& Lutfi (2020) yang membuktikan bahwa tidak terdapat perbedaan perilaku keuangan keluarga dilihat dari pendapatannya. Hasil penelitian ini juga mendukung Ida \& Dwinta (2010) yang membuktikan bahwa tidak adanya pengaruh pendapatan terhadap perilaku keuangan.

Hipotesis keempat dalam studi ini adalah pendapatan dapat memperkuat pengaruh pengetahuan keuangan pada perilaku pengelolaan keuangan. Temuan penelitian ini mengungkapkan bahwa pendapatan tidak memperkuat pengaruh pengetahuan keuangan terhadap perilaku keuangan. Dengan demikian maka dapat disimpulkan bahwa ketika seseorang memiliki pengetahuan keuangan yang baik dan memiliki pendapatan bulanan lebih tinggi maka orang tersebut tersebut belum tentu memiliki perilaku pengelolaan keuangan yang lebih bijak dibanding individu dengan pengetahuan serupa namun dengan penghasilannya lebih rendah. Terdapat beberapa kemungkinan penyebab hal ini. Pertama, sebagian besar responden memiliki pendapatan pada kisaran Rp.4 sampai dengan Rp.6 juta (54 persen). Dengan demikian, secara umum pendapatan tersebut cukup untuk memenuhi kebutuhan hidup seperti makan, minum, kendaraan maupun kesehatan. Pendapatan tidak memoderasi pengaruh pengetahuan keuangan terhadap perilaku keuangan juga dapat dikaitkan dengan life style atau gaya hidup yang dilakukan oleh generasi milenial di kota Surabaya, Gresik dan Sidoarjo. Seperti yang diketahui, Surabaya termasuk kota metropolitan dan Gresik serta Sidoarjo merupakan penyangga kota Surabaya. Kondisi ini mengakibatkan generasi milenial memiliki life style yang dapat dikatakan kurang baik, seperti praktek belanja impulsif dan liburan. Semakin individu memiliki pendapatan yang tinggi maka semakin tinggi kemungkinan hasrat individu untuk melakukan praktik belanja impulsif dan melakukan liburan kemanapun yang diinginkan. Walaupun memiliki pengetahuan yang lebih, individu yang memiliki pendapatan tinggi bisa saja tidak bisa menahan hasratnya untuk berbelanja, hiburan maupun liburan. Hal ini menyebabkan pendapatan yang lebih tinggi belum tentu mampu menyebabkan perilaku keuangan yang lebih baik 


\section{KESIMPULAN DAN SARAN}

Kesimpulan yang dapat diambil dari penelitian ini adalah bahwa lokus pengendalian internal dan pengetahuan keuangan berdampak positif pada perilaku keuangan generasi milenial. Tidak terdapat bukti signifikan bahwa pendapatan dapat mempengaruhi perilaku keuangan generasi milenial. Selain itu, pendapatan tidak mampu memperkuat pengaruh pengetahuan keuangan pada perilaku keuangan generasi milenial.

Hasil penelitian ini menyarankan bahwa generasi milenial sebaiknya lebih banyak mempelajari pengetahuan keuangan terkait investasi dan pengetahuan umum pribadi karena pengetahuan keuangan ini penting bagi pengelolaan keuangan yang baik, sedangkan skornya masih rendah. Generasi milenial juga perlu meningkatkan keyakinan dan kemampuan dalam mengendalikan kondisi keuangan sehari-hari karena faktor ini merupakan komponen penting dalam lokus pengendalian yang berdampak positif pada perilaku keuangan generasi milenial.

Keterbatasan utama penelitian ini adalah hanya mencakup wilayah penyebaran kuesioner pada tiga kota di Jawa Timur sehingga hasilnya tidak bisa digeneralisir untuk wilayah lain di Indonesia. Model penelitian ini juga hanya mampu menggambarkan variabel perilaku keuangan sebesar 26,5 persen, yaitu model agak lemah. Oleh karena itu, peneliti selanjutnya perlu lebih memperluas wilayah sampel penelitian yang mencakup berbagai kota di Indonesia serta menambahkan variabel lain yang bisa mempengaruhi perilaku manajemen keuangan, seperti pengalaman keuangan, keyakinan keuangan, kecakapan keuangan dan sikap keuangan.

Hasil penelitian ini mengimplikasikan bahwa pemerintah dan otoritas jasa keuangan perlu meningkatkan edukasi pengetahuan keuangan melalui seminar daring maupun sosial media karena saat ini generasi milenial lebih cenderung menggunakan gadget untuk mendapatkan segala informasi. Pengetahuan keuangan yang harus lebih diperhatikan adalah mengenai investasi karena memiliki skor terendah dibanding aspek pengetahuan keuangan lainya.

\section{REFERENSI}

Ariani, S., Rahmah, P. A. A. A., Putri, Y. R., Rohmah, M., Budiningrum, A., dan Lutfi, L. (2016). The Influence of Financial Literacy, Locus of Control, And Ethnicity on Investment Decision Making. Journal of Business \& Banking, 5(2), 257-270.

Arifin, A. Z., Kevin, K., dan Siswanto, H. P. (2017). Pengaruh Pengetahuan Keuangan, Kepercayaan Keuangan, dan Pendapatan terhadap Perilaku Keuangan pada Karyawan di Jakarta. Jurnal Ilmiah: MIX, VII(01), 37-47.

Arviana GN. (2020). Pahami 7 Karakteristik Generasi Milenial yang Unik. glints.com. Accessed March 1, 2021. https:/glints.com/id/lowongan/karakteristik-generasi- 
milenial

Badan Pusat Statistik. (2018). Sensus Penduduk Indonesia tahun 2019. Badan Pusat Statistik Indonesia.

Brailovskaia, J. dan Bierhoff, H. W. (2020). The Narcissistic Millennial Generation: A Study of Personality Traits and Online Behavior on Facebook. Journal of Adult Development, 27(1), 23-35.

Brilianti, T. R. dan Lutfi, L. (2020). The influence of Income, Financial Experience and Financial Knowledge on Family Financial Behavior in The City of Madiun. Journal of Business and Banking, 9(2), 197 - 213

Chen, H. dan Volpe, R. P. (1998). An Analysis of Personal Financial Literacy Among College Students. Financial Services Review, 107-128.

Cobb-Clark, D. A., Kassenboehmer, S. C., dan Sinning, M. G. (2016). Locus of Control and Savings. Journal of Banking \& Finance, 73, 113-130.

Dew, J. dan Xiao, J. J. (2011). A Deeper Review of The Literature Resulted in Eight More Studies that Used Financial Manage-Ment Behavior Scales. Journal of Financial Counseling and Planning, 22(1), 43-59.

Ghozali, I. dan Latan, H. (2013). Partial Least Square Konsep Aplikasi Path Modelling. Badan Penerbit Universitas Diponegoro, Semarang.

Grable, J. E., Joo, S. H., dan Park, J. (2015). Exploring The Antecedents of Financial Behavior for Asians and Non-Hispanic Whites: The Role of Financial Capability and Locus of Control. Journal of Personal Finance, 14(1), 28-37.

Grohmann, A. (2018). Financial literacy and Financial Behavior: Evidence from The Emerging Asian Middle Class. Pacific-Basin Finance Journal, 48, 129-143.

Heckman, S. J., dan Hanna, S. D. (2015). Individual and Institutional Factors Related to LowIncome Household Saving Behavior. Journal of Financial Counseling and Planning, 26(2), 187-199.

Hair Jr, J. F., Hult, G. T. M., Ringle, C., dan Sarstedt, M. (2016). A Primer on Partial Least Squares Structural Equation Modeling (PLSSEM). In, Sage publications

Henager, R., dan Mauldin, T. (2015). Financial literacy: The Relationship to Saving Behavior in Low-to Moderate-Income Households. Family and Consumer Sciences Research Journal, 44(1), 73-87.

Hilgert, M. A., Hogarth, J. M., dan Beverly, S. G. (2003). Household Financial Management: The Connection Between Knowledge and Behavior. Federal Reserve Bulletin, (Jul), 309322.

Ida dan Dwinta, C. Y. (2010). Pengaruh Lokus Pengendalian, Pengetahuan Keuangan, Pendapatan terhadap Perilaku Manajemen Keuangan. Jurnal Bisnis dan Akuntansi, 12(3), 131-144.

Iramani, R. dan Lutfi, L. (2021). An Integrated Model of Financial Well-Being: The Role of Financial Behavior. Accounting, 7(3), 691-700.

Kholilah, N. Al, dan Iramani, R. (2013). Studi Financial Management Behavior pada Masyarakat Surabaya. Journal of Business and Banking, 3(1), 69-80.

Kusnandar, D. L., Rinandiyana, L. R., dan Siliwangi, U. (2018). Apakah Menjadi Kekinian Merubah Perilaku Keuangan. Jurnal Ekonomi Manajemen, 4(1), 55-60.

Lubis, I. S. (2020). Perilaku Finansial Generasi Milenial. News.Detik.Com.

Nababan, D. dan Sadalia, I. (2012). Analisis Literasi Keuangan Pribadi dan Perilaku Keuangan Mahasiswa Sarjana Universitas Sumtera Utara. Media Informasi Manajemen, $1,1-16$.

Perry, V. G. dan Morris, M. D. (2005). Who is in Control? The Role of Self-Perception, Knowledge, and Income in Explaining Consumer Financial Behavior. Journal of Consumer Affairs, 39(2), 299-313. 
Purwidianti, W., dan Mudjiyanti, R. (2016). Analysis of The Influence of Financial Experience and Income Levels on Family Financial Behavior. Benefit: Jurnal Manajemen dan Bisnis, 1(2), 141-148.

Putri, I. R. dan Tasman, A. (2019). Pengaruh Literasi Keuangan dan Pendapatan terhadap Perilaku Manajemen Keuangan Personal pada Generasi Milenial. Jurnal Kajian Manajemen dan Wirausaha, 01(1), 151-160.

Rotter, J. B. (1966). Generalized Expectancies for Internal Versus External Control of Reinforcement. Psychological Monographs: General and Applied, 80(1), 1-28.

Stolper, O. A., dan Walter, A. (2017). Financial Literacy, Financial Advice, and Financial Behavior. Journal of Business Economics, 87(5), 581-643.

Strömbäck, C., Lind, T., Skagerlund, K., Västfjäll, D., dan Tinghög, G. (2017). Does SelfControl Predict Financial Behavior and Financial Well-Being? Journal of Behavioral and Experimental Finance, 14, 30-38.

Xiao, J. J. (2008). Applying Behavior Theories to Financial Behavior. in Handbook of Consumer Finance Research (pp. 69-81). Springer, New York, NY. 